\section{Antidiarrheal activity of Solanum asterophorum in mice}

\section{Polyana Cristina Barros Silva, ${ }^{1,2}$ José Clementino Neto, ${ }^{3}$ Anne Dayse S. da Silva, ${ }^{3}$ Karoline de Melo e Silva, ${ }^{3}$ Tania Maria S. Silva, ${ }^{4}$ Maria de Fátima Agra, ${ }^{2}$ Fabiana de Andrade Cavalcante $^{* 1,3}$}

${ }^{1}$ Pós-graduação em Nutrição, Universidade Federal de Alagoas, Brazil,

${ }^{2}$ Laboratório de Tecnologia Farmacêutica "Prof. Delby Fernandes de Medeiros", Universidade Federal da Paraiba, Brazil,

${ }^{3}$ Instituto de Ciências Biológicas e da Saúde, Universidade Federal de Alagoas, Brazil,

${ }^{4}$ Departamento de Química, Universidade Federal Rural de Pernambuco, Brazil.
Revista Brasileira de Farmacognosia Brazilian Journal of Pharmacognosy 22(1): 131-136, Jan./Feb. 2012 Available online 30 Sep 2011

\begin{abstract}
Several species of Solanum are used in folk medicine to treat diarrhea. Therefore, the aim of this study was to investigate and compare possible antidiarrheal activity of methanol extracts from roots $\left(\right.$ Sast- $\left.\mathrm{MeOH}_{\mathrm{R}}\right)$ and leaves $\left(\right.$ Sast- $\left.\mathrm{MeOH}_{\mathrm{L}}\right)$ of Solanum asterophorum Mart., Solanaceae, in mice. Sast- $\mathrm{MeOH}_{\mathrm{R}}$ was shown to significantly and dose-relatedly inhibit the frequency of both solid (ED50 $309.6 \pm 28.5 \mathrm{mg} / \mathrm{kg}$ ) and liquid (ED50 $152.1 \pm 32.5 \mathrm{mg} / \mathrm{kg}$ ) stools. Conversely, Sast$\mathrm{MeOH}_{\mathrm{L}}$ significantly inhibited solid stool frequency only when dosed at 500 and $750 \mathrm{mg} / \mathrm{kg}(48.7 \pm 7.4$ and $42.3 \pm 9.8 \%$, respectively), but also significantly and doserelatedly inhibited liquid stools (ED50 268.4 $\pm 35.2 \mathrm{mg} / \mathrm{kg}$ ). Thus, Sast-MeOH $\mathrm{M}_{\mathrm{R}}$ was

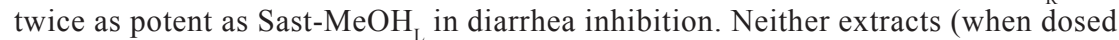
up to $500 \mathrm{mg} / \mathrm{kg}$ ) inhibited intestinal transit. However, both extracts significantly and dose-relatedly inhibited intestinal fluids, and Sast- $\mathrm{MeOH}_{\mathrm{R}}(\mathrm{ED} 50$ 38.3 \pm 10.4 $\mathrm{mg} / \mathrm{kg}$ ) was again twice as potent as Sast- $\mathrm{MeOH}_{\mathrm{L}}(\mathrm{ED} 5078.6 \pm 6.4 \mathrm{mg} / \mathrm{kg}$ ). Results suggest that antidiarrheal effects of Sast- $\mathrm{MeOH}_{\mathrm{R}}$ and Sast- $\mathrm{MeOH}_{\mathrm{L}}$ involve changes on intestinal secretion. In addition, active metabolites with antidiarrheal activity may be more concentrated in the roots of this species. However further studies are needed to elucidate the action mechanism involved in this activity.
\end{abstract}

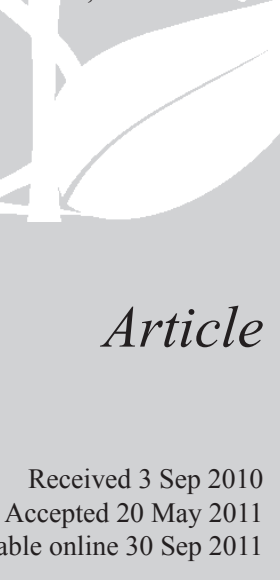

Received 3 Sep 2010 Accepted 20 May 2011

Keywords: antidiarrheal effect in vivo study leaves roots Solanum asterophorum

ISSN 0102-695X http://dx.doi.org/10.1590/S0102$695 \mathrm{X} 2011005000178$

\section{Introduction}

Diarrhea is one of the most common diseases in children worldwide and is characterized by an increase in the number of stools ( 3 or more $/ 24 \mathrm{~h}$ ), increased fluidity of stools and/or the presence of blood/mucus in these (Mathan, 1998). It affects people of any age, but is in childhood that this condition may cause higher mortality. It is the third most common cause of disease in children in developing countries and is responsible for about one third of all hospitalizations among children under five years (Souza, 2000). Many plants are used as antidiarrheal in folk medicine, such as Psidium guajava ("guava"), Stachytarpheta cayenensis ("Brazilian tea"), Eugenia uniflora ("Brazilian cherry"), Anacardium occidentale ("cashew"), Mangifera indica ("mango") and Egletes viscosa ("macela") (Almeida et al., 1995; Agra et al., 2008).

There are many Angiosperm families in
Northeast Brazil, among which Solanaceae A. L. Jussieu stands out, with 96 genera and 3000 species (Hunziker, 2001). The genus Solanum L. is the most representative of this family, with circa 1400 species (Bohs, 2005) and 5000 described epithets (Nee, 1999), inhabiting tropical and subtropical regions of the world (Agra \& Bhattacharyya, 1999). Several species of Solanum are known in folk medicine for showing antidiarrheal activity, such as Solanum marginatum (Abebe, 1986), Solanum khasianum (Jain \& Puri, 1984), Solanum torvum (Dominguez \& Alcorn, 1985) and Solanum xanthocarpum (Jain \& Puri, 1984).

Solanum asterophorum Mart., Solanaceae, is a shrubby species, popularly known as "jurubebade-fogo". In Brazil, it is found in Paraiba and Bahia, with indications of folk medicine use against liver dysfunctions (Agra \& Bhattacharyya, 1999). Pharmacological studies show that methanol extracts obtained from aerial parts and roots of Solanum 
astherophorum are bioactive for Artemia salina but have no bioactivity for mollusks (Silva et al., 2007). When studying acute toxicity, Oliveira (2006) showed that the methanol extract obtained from leaves (Sast$\mathrm{MeOH}_{\mathrm{L}}$ ) of this species did not produce nor induce behavioral changes and death in mice, while Oliveira et al. (2006) demonstrated that the same extract (Sast$\mathrm{MeOH}_{\mathrm{L}}$ ) and the alkaloid isojuripidine isolated from its aerial parts (Silva et al, 2005) did not induce erythrocyte hemolysis in rats, but induced relaxation in guinea pig ileum through voltage-dependent calcium channels type $1.2\left(\mathrm{Ca}_{\mathrm{v}} 1.2\right)$.

Since many Solanum species show antidiarrheal activity and $S$. astherophorum have shown spasmolytic activity in guinea pig ileum, i.e., reduced its contractibility, we decided to investigate and compare possible antidiarrheal activity of methanol extracts from roots $\left(\right.$ Sast- $\left.\mathrm{MeOH}_{\mathrm{R}}\right)$ and leaves $\left(\mathrm{Sast}-\mathrm{MeOH}_{\mathrm{L}}\right)$ of this species, using castor oil-induced diarrhea models in mice.

\section{Material and Methods}

\section{Plant material}

Solanum asterophorum Mart., Solanaceae, was collected in the municipality of Areia, Paraíba, Brazil, and identified by Dr. Maria de Fátima Agra at the Laboratório de Tecnologia Farmacêutica "Prof. Delby Fernandes de Medeiros", Universidade Federal da Paraíba. The voucher specimens are deposited in the Herbarium Prof. Lauro Pires Xavier (JPB), UFPB, and duplicates are deposited in the Reference Collection of LTF/UFPB under the identification code "Agra 6002". Powdered aerial parts and roots were extracted with $\mathrm{MeOH}$ in a Soxhlet apparatus. The extract was concentrated under vacuum in rotaevaporator. The crude residue was subjected to experiments.

\section{Animals}

Female and male Swiss mice (Mus musculus) from the Central Animal Laboratory, Universidade Federal de Alagoas, weighing between 25 and 35 g, were used. Previous to the experiments, the animals were kept under strict control feeding with a balanced diet based on food pellet type and had free access to water, both room ventilation and temperature $\left(21 \pm 1{ }^{\circ} \mathrm{C}\right)$ were controlled and constant. All experimental procedures with Solanum astherophorum were submitted and approved by the Ethical Committee in Research of UFAL (No. 027241/2008 11).

\section{Substances}

Atropine and Cremophor ${ }^{\circledR}$ were obtained from
Sigma-Aldrich(USA). Carboxymethylcelluloseand castor oil were obtained from Formula, Brazil. Loperamide was obtained from Janssen Cilag Farmacêutica Ltda, Brazil, and the activated charcoal obtained from Proquímios, Brazil.

\section{Preparation of extracts for pharmacological tests}

The crude methanol extracts were obtained

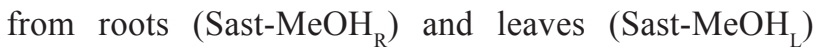
of Solanum astherophorum. These were solubilized in Cremophor $^{\circledR}(3 \%)$ and diluted in distilled water to obtain stock solutions $(500 \mathrm{mg} / \mathrm{mL})$. Upon completion of the experimental protocols the solutions were diluted with distilled water or saline, according to the requirement of each protocol.

Pharmacological behavioral screening and determination of LD50 of Sast-MeOH

The Sast- $\mathrm{MeOH}_{\mathrm{R}}$ extract was administered orally (p.o.) or intraperitoneally (i.p.) to groups of five males and five females (one dose per group), which fasted for $12 \mathrm{~h}$. Simultaneously, control animals received $10 \mathrm{~mL} /$ $\mathrm{kg}$ plus Cremophor ${ }^{\circledR}$. General signs and symptoms of toxicity, such as analgesia, contortions, aggression and diarrhea, were recorded for $3 \mathrm{~h}$. The animals were also evaluated at 24,48 and $72 \mathrm{~h}$ in order to observe if there was any death.

Evaluation of antidiarrheal activity of Sast-MeOH$H_{R}$ and Sast- $\mathrm{MeOH}_{L}$

Castor oil-induced diarrhea in mice (Awouters et al., 1978)

Male mice were divided into groups $(n=6)$ and gavaged with $0.9 \%$ saline solution $10 \mathrm{~mL} / \mathrm{kg}$ plus Cremophor $^{\circledR}$ (negative control), loperamide $10 \mathrm{mg} / \mathrm{kg}$ (positive control) and Sast-MeOHR or Sast-MeOHL (doses ranging from 62.5 to $750 \mathrm{mg} / \mathrm{kg}$ ). After $1 \mathrm{~h}, 0.01$ $\mathrm{mL}$ of castor oil per gram was administered orally to each animal to induce diarrhea and the counting and consistency of dung pats was assessed for $3 \mathrm{~h}$, classifying them according to consistency in solids or liquids. ED50 values (dose of a substance that produces $50 \%$ of its maximum effect) were obtained by nonlinear regression and expressed as a percentage of the mean \pm SEM.

\section{Intestinal transit in mice (Rao et al., 1997)}

Male mice were divided into groups $(n=6)$ and gavaged with $0.9 \%$ saline solution $10 \mathrm{~mL} / \mathrm{kg}$ plus Cremophor $^{\circledR}$ (negative control), atropine $2 \mathrm{mg} / \mathrm{kg}$ (positive control) and Sast- $\mathrm{MeOH}_{\mathrm{R}}$ or Sast- $\mathrm{MeOH}_{\mathrm{L}}$ (doses 
ranging from 62.5 to $750 \mathrm{mg} / \mathrm{kg}$ ). After $30 \mathrm{~min}, 0.01 \mathrm{~mL}$ of activated charcoal $(5 \%)$ in carboxymethylcellulose $(0.5 \%)$ solution was administered orally per gram to each animal, which was euthanized by cervical dislocation after $30 \mathrm{~min}$. The abdominal cavity was opened and the small intestine removed. With the aid of a ruler, its total length (distance between the pylorus and the ileocecal valve) and the distance traveled by the marker were assessed for each animal. The results were expressed as a percentage of the distance traveled by the marker in relation to the total length.

Intestinal fluid accumulation induced by castor oil in mice (DiCarlo et al., 1994)

Male mice, fasted for $24 \mathrm{~h}$ with free access to water, were divided into groups $(\mathrm{n}=6)$ and gavaged with $0.9 \%$ saline solution $10 \mathrm{~mL} / \mathrm{kg}$ plus $\mathrm{Cremophor}^{\circledR}$ (negative control) and Sast- $\mathrm{MeOH}_{\mathrm{R}}$ or Sast- $\mathrm{MeOH}_{\mathrm{L}}$ (doses ranging from 25 to $125 \mathrm{mg} / \mathrm{kg}$ ). After $30 \mathrm{~min}, 2 \mathrm{~mL}$ of castor oil was administered per animal. After other $30 \mathrm{~min}$, the mice were euthanized, the small intestine was dissected from pylorus throughout cecum and the contents were collected into a beaker to assess the volume of fluid. ED50 values were calculated as previously.

\section{Statistical analysis}

All results were expressed as a percentage of the mean \pm SEM, and differences between means were statistically analyzed through t-test (non-paired) or one-way analysis of variance (ANOVA) followed by Bonferroni correction with $p<0.05$ values considered significant. ED50 and Emax values were assessed through nonlinear regression. All data were analyzed using GraphPad Prism version 3.03 software (GraphPad Software Inc., San Diego, CA, USA).

\section{Results and Discussion}

In this study we investigated and compared a possible antidiarrheal activity of crude methanol extract obtained from roots $\left(\right.$ Sast- $\mathrm{MeOH}_{\mathrm{R}}$ ) and leaves (Sast$\mathrm{MeOH}_{\mathrm{L}}$ ) of Solanum asterophorum Mart., Solanaceae, in mice. For the first time, the strong antidiarrheal activity displayed by Sast- $\mathrm{MeOH}_{\mathrm{R}}$ and Sast- $\mathrm{MeOH}_{\mathrm{L}}$ extracts was demonstrated.

Since many species of Solanum are used in diarrhea treatment (Abebe, 1986; Jain \& Puri, 1984; Dominguez \& Alcorn, 1985) and Solanum astherophorum leaf extracts exhibit antispasmodic activity (Oliveira et al., 2006), we hypothesized that these extracts might contain antidiarrheal active metabolites.

The most frequent metabolites in Solanum species are from the alkaloid family, the steroidal alkaloids solasonine and solamargine being found in more than 100 of its species (Blankemeyer et al., 1998; Mesia-Vela et al., 2002), and toxic activity is attributed to these alkaloids (Jadhay et al., 1981; Blankemeyer et al., 1998). Due to the great interest by folk medicine in compounds from Solanaceae plants, many studies have been developed trying to evaluate the toxicological activity of Solanum species (Shakunda \& Chester, 1976; Maruo et al., 2003; Heo \& Lim, 2005).

Oliveira (2006) showed that Sast- $\mathrm{MeOH}_{\mathrm{L}}$ extract did not produce behavioral changes nor did it induce death in mice in an acute toxicity study. Since this is a pioneer work on $S$. astherophorum roots, the acute toxicological potential of Sast- $\mathrm{MeOH}_{\mathrm{R}}$ extract was assessed and a pharmacological monitoring on diarrhea experimental models was conducted.

The administration of Sast- $\mathrm{MeOH}_{\mathrm{R}}$ extract orally at doses between 2500 and $5000 \mathrm{mg} / \mathrm{kg}$ and intraperitoneally at doses between 1000 and $2000 \mathrm{mg} /$ $\mathrm{kg}$ in mice of both sexes also did not produce toxicitycharacteristic behavioral changes such as sedation, aggression, urination, diarrhea, convulsion, loss of corneal reflex and ear, piloerection and writhing, nor induced death. Thus, it was not possible to assess LD50 for the tested extracts. The fact that both the root and leaf extracts are devoid of systemic toxicity allowed us a safe choice of the doses used in the experimental protocols performed in order to investigate the antidiarrheal effect of these extracts.

Diarrhea results from rapid movement of fecal matter through the large intestine (Guyton \& Hall, 2006). To restore this process, many patients require antidiarrheal therapy in order to increase flow resistance and mucosal absorption and decrease secretion (Akindele \& Adeyemi, 2006). To verify the antidiarrheal effect of Sast- $\mathrm{MeOH}_{\mathrm{R}}$ and Sast- $\mathrm{MeOH}_{\mathrm{L}}$, castor oil was used since it is widely employed for screening drugs with this property. One of the advantages of this model is the high reproducibility of the evacuation of stool formed in less than one hour after the administration of laxatives (Borrelli et al., 2006). The results of oral administration of loperamide $(10 \mathrm{mg} / \mathrm{kg})$ and Sast$\mathrm{MeOH}_{\mathrm{R}}(250,500$ and $750 \mathrm{mg} / \mathrm{kg})$ showed that there was significant dose-related inhibition of defecation frequency $(97.9 \pm 2.1,34.3 \pm 5.6,47.8 \pm 9.7$ and $70.1 \pm 6.3$, respectively) when compared to the negative control $\left(0.9 \%\right.$ saline solution $\left.+\mathrm{Cremophor}^{\circledR}\right)$ (Figure 1A). Regarding liquid stools, both loperamide $(10 \mathrm{mg} /$ $\mathrm{kg})$ and Sast- $\mathrm{MeOH}_{\mathrm{R}}(125,250,500$, and $750 \mathrm{mg} / \mathrm{kg})$ showed significant, dose-related inhibition percentages of $43.6 \pm 4.4,58.0 \pm 8.5,80.6 \pm 12.6$ and 100 , respectively (Figure 1B). On the other hand, Sast- $\mathrm{MeOH}_{\mathrm{L}}$ extract (Figure 2A) showed significant inhibitory effect on defecation frequency only when dosed at 500 and

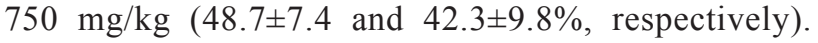


Regarding liquid stools, Sast- $\mathrm{MeOH}_{\mathrm{L}}$ extract showed inhibitory effect when dosed at 250,500 and $750 \mathrm{mg} /$ $\mathrm{kg}$, with significant dose-related inhibition frequencies of $32.9 \pm 10.1,80.6 \pm 11.1$ and $88.4 \pm 5.2 \%$, respectively (Figure 2B). Regarding defecation frequency, only Sast- $\mathrm{MeOH}_{\mathrm{R}}$ produced dose-related inhibition, with $309.6 \pm 28.5 \mathrm{mg} / \mathrm{kg}$ ED50. However, for liquid stools, Sast- $\mathrm{MeOH}_{\mathrm{R}}$ extract (ED50 $152.1 \pm 32.5 \mathrm{mg} / \mathrm{kg}$ ) was more effective than Sast$\mathrm{MeOH}_{\mathrm{L}}(\mathrm{ED} 50268.4 \pm 35.2 \mathrm{mg} / \mathrm{kg})$ in inhibiting diarrhea. Therefore, both Sast- $\mathrm{MeOH}_{\mathrm{R}}$ and Sast- $\mathrm{MeOH}_{\mathrm{L}}$ produced significant inhibitory effect on diarrhea in mice in this induction model, as observed by reducing both solid and liquid stool frequencies, suggesting that both extracts have active metabolites with antidiarrheal activity. Conversely, the root extract showed stronger antidiarrheal effect than that from the leaves, suggesting that the active antidiarrheal metabolites are more frequent in the former than in the latter.

Clinically, diarrhea is a consequence of intestinal function disorders which lead to excessive intestinal secretion, impaired intestinal absorption and/ or rapid transit (Menezes et al., 1994). Therefore, the antidiarrheal effect of the extracts was studied with experimental castor oil-induced diarrhea models and castor oil-induced intestinal transit and intestinal fluid accumulation in mice. Drugs that inhibit intestinal transit in pathophysiological states may be effective in relieving diarrhea (Borrelli et al., 2006). Activated charcoal, employed in the gastrointestinal transit model as a marker, has been used for over 60 years as a simple tool for evaluating the effect of laxatives (Gaginella et al., 1994). This method is an indicator of the maximum distance traveled by the marker (activated charcoal) through its administration and the assessment of its path in the small intestine over a period of time (Gurgel, 2000). According to this model, the results of oral administration of atropine $(2 \mathrm{mg} / \mathrm{kg})$ show that there was significant inhibition of the distance traveled by charcoal in the intestine of mice of circa $32.7 \pm 3.6 \%$, when compared to the negative control

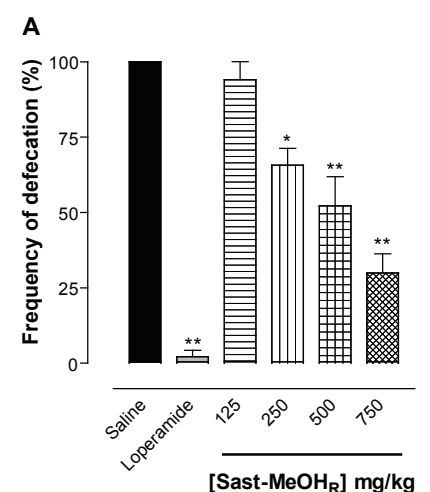

$\left(0.9 \%\right.$ saline + Cremophor $\left.^{\circledR}\right)$. Still, neither Sast $-\mathrm{MeOH}_{\mathrm{R}}$ nor Sast- $\mathrm{MeOH}_{\mathrm{L}}$ extracts reduced the distance travelled by the marker when dosed at 125,250 or $500 \mathrm{mg} / \mathrm{kg}$ (data not shown).

Though it is common belief that the small intestine plays only an absorptive role, it also secretes water and electrolytes. This enhanced secretory capacity is clearly shown through the administration of large amounts of castor oil (Gurgel, 2000). Thus, we assessed the effects of Sast- $\mathrm{MeOH}_{\mathrm{R}}$ and Sast- $\mathrm{MeOH}_{\mathrm{L}}$ extracts in mice using a castor oil-induced intestinal fluid accumulation model and evaluated the fluid amount in comparison to the control group. Loperamide $(69.2 \pm 1.5 \%)$, Sast- $\mathrm{MeOH}_{\mathrm{R}}$ and $\mathrm{Sast}-\mathrm{MeOH}_{\mathrm{L}}$ extracts inhibited significantly and dose-relatedly the intestinal fluid content induced by castor oil dosed at 25, 50, 75, 100 and $125 \mathrm{mg} / \mathrm{kg}$ in comparison to negative control $\left(0.9 \%\right.$ saline + Cremophor $\left.^{\circledR}\right)$. When compared to the negative control, inhibition values for the Sast- $\mathrm{MeOH}_{\mathrm{R}}$ extract were $21.6 \pm 7.5,30.4 \pm 4.9,42.2 \pm 2.4,60.8 \pm 3.0$ and $71.1 \pm 2.4 \%$, respectively, and $37.2 \pm 6.4,52.9 \pm 4.0$, $51.0 \pm 4.5$ and $59.3 \pm 2.5 \%$ for Sast-MeOHL, respectively (Figure 3). Sast-MeOH $\mathrm{R}_{\mathrm{R}}$ extract (ED50 $38.3 \pm 10.4 \mathrm{mg} /$ $\mathrm{kg}$ ) was about twice as effective as Sast- $\mathrm{MeOH}_{\mathrm{L}}(\mathrm{ED} 50$ $78.6 \pm 6.4 \mathrm{mg} / \mathrm{kg}$ ) in inhibiting intestinal fluid content, reinforcing the idea that the secondary metabolites with antidiarrheal activity are more frequent in the roots than in the leaves.

The most important conclusions of this study are the inedited demonstrations that Solanum astherophorum Mart. displays antidiarrheal activity, which surely brings great contribution to the pharmacology of this species, as well as showing that the root extract has more effective antidiarrheal activity than the leaf extract. Since steroidal alkaloid isojuripidine was isolated from the aerial parts of $S$. asterophorum, part of this activity can be attributed to it. Further studies are needed, including verifications of the amount and type of root alkaloids.

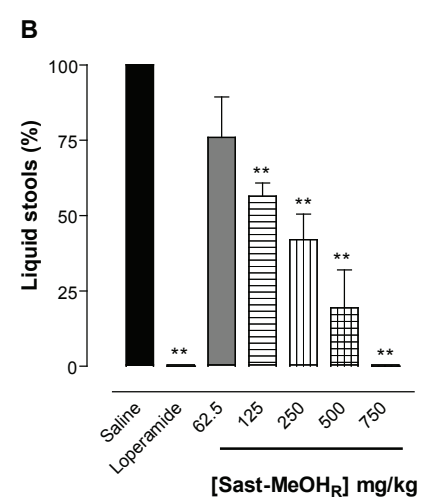

Figure 1. Antidiarrheal effect of Sast- $\mathrm{MeOH}_{\mathrm{R}}$ extract on castor oil-induced diarrhea model in mice ( $\left.\mathrm{n}=6\right)$. A. Percentage frequency of defecation, and B. Percentage of liquid stools. Columns and vertical bars represent the percentage of mean and SEM, respectively. One-way ANOVA followed by Bonferroni, ${ }^{*} p<0.05$ and ${ }^{*} p<0.001$ (Saline $v s$. Loperamide/Sast- $\mathrm{MeOH}_{\mathrm{R}}$ ). 
A

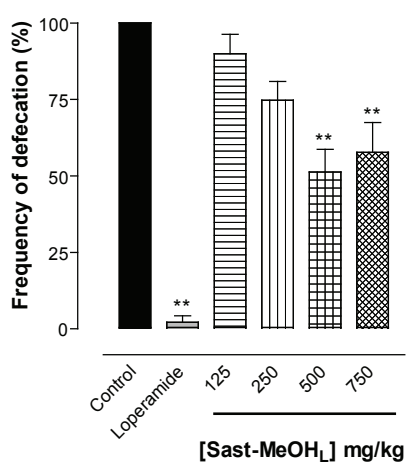

B

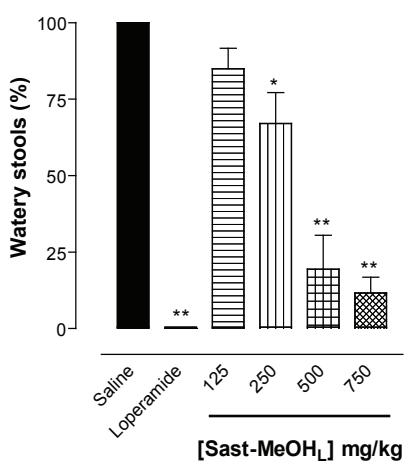

Figure 2. Antidiarrheal effect of Sast- $\mathrm{MeOH}_{\mathrm{F}}$ extract on castor oil-induced diarrhea model in mice $(\mathrm{n}=6)$. A. Percentage frequency of defecation, and B. Percentage of liquid stools. Columns and vertical bars represent the percentage of mean and SEM, respectively. One-way ANOVA followed by Bonferroni, ${ }^{*} p<0.05$ and $* * p<0.001$ (Saline vs. Loperamide/Sast$\left.\mathrm{MeOH}_{\mathrm{L}}\right)$.

A

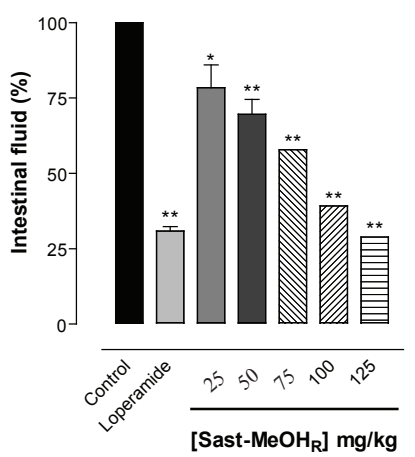

B

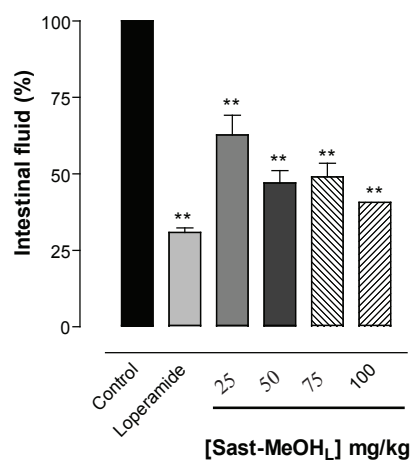

Figure 3. Effect of Sast- $\mathrm{MeOH}_{\mathrm{R}}$ A and Sast- $\mathrm{MeOH}_{\mathrm{L}}$ B extracts on castor oil-induced intestinal fluid accumulation in mice (n=6). Columns and vertical bars represent the percentage of mean and SEM, respectively. One-way ANOVA followed by Bonferroni, ${ }^{*} p<0.05$ and $* * p<0.001$ (Saline $v s$. Loperamide/extracts).

\section{Acknowledgment}

The authors thank the financial support by PIBIC/UFAL and FAPEAL.

\section{References}

Abebe W 1986. A survey of prescriptions used in traditional medicine in Gondar region, northwestern Ethiopia: general pharmaceutical practice. J Ethnopharmacol 18: 147-165.

Agra MF, Bhattacharyya J 1999. Ethnomedicinal and phytochemical investigation on the Solanum species in the Northeast of Brazil. In: Nee M, Symon DE, Lester RN, Jessop JP. (Eds). Solanaceae IV, Royal Botanic Gardens, Kew, p. 341-343.

Agra MF, Silva KN, Basílio IJLD, Freitas PF, Barbosa-Filho JM 2008. Survey of medicinal plants used in the region Northeast of Brazil. Rev Bras Farmacogn 18: 472-508. Akindele AJ, Adeyemi OO 2006. Evaluation of the antidiarrhoeal activity of Byrsocarpus coccineus. $J$ Ethnopharmacol 108: 20-25.

Almeida CE, Karnikowski MGO, Foleto R, Baldisserotto B 1995. Analysis of antidiarrhoeic effect of plants used in popular medicine. Rev Saude Publ 29: 428-33.

Awouters F, Neimegeers CJE, Lenaert FM, Janssen 1978. Delay of castor oil diarrhoea in rats; A new way to evaluate inhibitors of prostaglandin's biosynthesis. J Pharm Pharmacol 30: 41-45.

Blankemeyer JT, Mcwilliams ML, Rayburn JR, Weissenberg M, Friedman M 1998. Developmental toxicology of solamargine and solasonine glycolalkaloids in frog embryos. Food Chem Toxicol 36: 383-389.

Bohs L 2005. Major clades in Solanum based on ndhF sequences. In Keating RC, Hollowell VC, Croat TB (eds.) Monographs in Systematic Botany from the Missouri Botanical Garden. A festschrift for William G. D'Arcy: the legacy of a taxonomist. St. Louis, Missouri Botanical Garden Press 104: 27-49.

Borrelli F, Capasso F, Capasso R, Ascione V, Aviello G, Longo 
L, Izzo AA 2006. Effect of Boswellia serrata on intestinal motility in rodents: inhibition of diarrhoea without constipation. Brit J Pharmacol 148: 553-560.

Dicarlo GD, Mascolo N, Izzo AA, Capasso F 1994. Effect of quereetine on the gastrintestinal tract in rats and mice. Phytother Res 8: 42-45.

Dominguez XA, Alcorn JB 1985. Screening of medicinal plants used by huastec mayans of northeastern Mexico. $J$ Ethnopharmacol 13: 139-156.

Gaginella TS, Mascolo N, Izzo AA, Autore G, Capasso F 1994. Nitric oxide as a mediator of bisacodyl and phenolphthalein laxative action: induction of nitric oxide synthase. J Pharmacol Exp Ther 270: 12391245.

Gurgel LA 2000. Avaliação experimental da atividade antidiarréica do látex do Croton urucurana Baill. Fortaleza, 146 p. Dissertação de mestrado. Departamento de Fisiologia e Farmacologia. Centro de Ciências da Saúde. Universidade Federal do Ceará.

Guyton AC, Hall JE 2006. Tratado de Fisiologia Médica. Elsevier. Rio de Janeiro, p. 822-823.

Heo KS, Lim KT 2005. Glicoprotein isolated from Solanum nigrum L. modulates the apoptotic-related signals in 12$o$-tetradecanoylphorbol 13-acetate-stimulated MCF-7 cells. J Med Food 8: 69-77.

Hunziker AT 2001. Genera Solanacearum: The genera of Solanaceae illustrated, arranged according to a new system. A. R. Gantner Verlag, Köenigstein, p. 401-486.

Jain SP, Puri HS 1984. Ethnomedicinal plants of jaunsar-bawar hills, uttar pradesh, india. J Ethnopharmacol 12: 213 222.

Jadhay SJ, Sharma RP, Salunkhe DK 1981. Naturally occurring toxic alkaloids in foods. Toxicology 9: 21-104.

Maruo VM, Bernardi MM, Spinosa HS 2003. Toxicological evaluations of long-term consumption of Solanum lycocarpum St. Hill fruits in male and female adult rats. Phytomedicine 10: 48-52.

Mathan VI 1998. Diarrhoeal diseases. Brit Med Bull 54: 402419.

Menezes MAS, Viana GSB, Vietla SNR, Corrêa RA, Feijó SGF 1994. Estudo farmacológico. In: Viana GSB, Matos FJA, Bandeira MAM, Rao VSN. Aroeira do sertão (Myracrodruon urundeuva Fr. All.). Fortaleza, UFC 187: 83-174.

Mesia-Vela S, Santos MT, Souccar C, Lima-Landman MTR, Lapa AJ 2002. Solanum paniculatum L. (Jurubeba):
Potent inhibitor of gastric acid secretion in mice. Phytomedicine 9: 508-514.

Nee M 1999. Synopsis of Solanum in the New World. In: Nee M, Symon DE, Lester RN, Jessop JP. Solanaceae IV: Advances in Biology and Utilization. Royal Botanic Gardens, Kew, p. 285-333.

Oliveira RCM 2006. Efeito antiinflamatório, antinociceptivo e espasmolítico de Solanum megalonyx Sendtn. e Solanum asterophorum Mart. (Solanaceae): um estudo comparativo. João Pessoa, 123 p. Tese de doutorado, Programa de Pós-graduação em Produtos Naturais e Sintéticos Bioativos. Universidade Federal da Paraíba.

Oliveira RCM, Lima JT, Ribeiro LAA, Silva JLV, Monteiro FS, Assis TS, Agra MF, Silva TMS, Almeida FRC, Silva BA 2006. Spasmolytic action of the methanol extract and isojuripidine from Solanum asterophorum Mart. (Solanaceae) leaves in guinea-pig ileum. Z Naturforsch C 61: 799-805.

Rao VSN, Santos FA, Sobreira TT, Souza MF, Melo CL, Silveira ER 1997. Investigations on the gastroprotective and antidiarrhoeal properties of ternatin, a tetramethoxyfl avone from Egletes viscose. Planta Med 63: 146-149.

Shakunda C, Chester AS 1976. Teratological and toxicological studies of alkaloidal and phenolic compounds from Solanum tuberosum L. Toxicol Appl Pharm 36: $227-$ 237.

Silva TMS, Costa RA, Oliveira EJ, Barbosa-Filho JM, Agra MF, Camara CA 2005. Complete ${ }^{1} \mathrm{H}$ and ${ }^{13} \mathrm{C}$ NMR assignments of Isojurupidine from Solanum asterophorum Mart. J Brazil Chem Soc 16: 1467-1471.

Silva TMS, Nascimento RJB, Batista MM, Agra MF, Camara CA 2007. Brine shrimp bioassay of some species of Solanum from Northestern Brazil. Rev Bras Farmacogn 17: 35-38.

Souza EC 2000. Perfil etimológico das diarréias agudas em crianças atendidas em um pronto socorro de hospital regional da cidade de São Paulo. São Paulo. Dissertação de Mestrado. Faculdade de Medicina/USP.

\section{*Correspondence}

Fabiana de Andrade Cavalcante

Instituto de Ciências Biológicas e da Saúde, Universidade Federal de Alagoas

Caixa Postal 57010-020 Maceió-AL, Brazil

fabiana.andrade@ccbi.ufal.br

Tel. +55 8233363444,8232232501 